\title{
Values of Rinjani Charter in The Life of Suku Sasak at West Nusa Tenggara
}

\author{
Sri Rejeki \\ Universitas Muhammadiyah Mataram \\ Lombok, Indonesia \\ umi.cici.66@gmail.com
}

\begin{abstract}
The purpose of this research is to know the influence of Rinjani Charter values in the life of Sasak tribe in West Nusa Tenggara. The subject of this research is one of the figures directly involved in the preparation of the Rinjani Charter. The object of the study is the text of the Rinjani Charter and the things that encourage the birth of the Rinjani Charter. Methods of data collection with in-depth interviews and documentation. Data analysis uses qualitative data analysis steps James P. Spardly. The conclusion of this research is the birth of Rinjani Charter signed on June 17, 2005 has impact to social function of society especially in environmental conservation and life of Sasak tribe that make Mount Rinjani become life source. The Rinjani Charter reinforces the wishes of the Sasak community in the preservation of values, culture and life in a broad sense. In the belief system of Sasak, Rinjani is the navel of the earth and at the same time as the "pasak bumi" with various cosmological power possessed. This belief system gave birth to a variety of ceremonial systems and "taboo" systems in order to breed and honor as a form of gratitude. Mount Rinjani became the ecological center (pasek gumi) Lombok Island which is the source of water that affects the climatology and life on the island of Lombok.
\end{abstract}

Keywords-values; Rinjani charter; suku sasak

\section{INTRODUCTION}

Gumi paer commonly called Paer is a symbolic formulation of Sasak people's understanding of space in cultural perspectives. Paer is not only a geographical and cosmological concept, but it also has sociological interpretations. In the belief system Sasak Rinjani is the navel of the earth and at the same time as pasak bumi with various cosmological power possessed. This belief system gave birth to a variety of ceremonial systems and taboo systems in order to breed and honor as a form of gratitude. Rinjani as the center of the cosmos and the ecological center (pasek gumi) Lombok Island that flows water sources that affect the climatology and life of Lombok Island as the current understanding. Rinjani Mountain is not just a mountain that many in the tramp of nature lovers, but the mountain Rinjani save a lot value growing in the life of the Sasak people.

Based on preliminary studies through interviews and documentation, there are many things that led to the birth of the Rinjani Charter, which is central to the monopoly of interests and poverty which resulted in:
- The seizure of water in the rinjani area, all municipalities have the right of water from rinjani, the problem of PDAM to seize water sources, including water companies, without recourse to sustainable conditions, water debit evidence decreases every year.

- Biodiversity has degradation, many destruction of biodiversity good flora of its fauna. Reduced animal populations around the rinjani.

- Many forests have been deforested due to the inclusion of the society since 1998, since the collapse of the Order, due to the lack of income from outside the reduced Lombok, the higher poverty around the area, the rapid development in NTB.

- Mine, high poverty factor, low education level and low income, then they unearth uncompromising pumice stone, regardless of impact.

- Land, the quality of the soil is low, because the forest is bare, often landslide.

- Values people began to degrade because of the entry of outside cultures that are not in accordance with the values of the Sasak community, such as changes in social relationships, patterns of child and parent relationships, patterns of kinship life, land governance, and ways of looking fortune.

\section{LITERATURE REVIEW}

In Negarakertagama, Antoro mentioning "Lombok Mirah Sasak Adi", Lombok in Kawi means honest or straight, mirah means gem, sasak means reality and adi means good or main. Then the overall meaning of "honesty is the jewel of the good or the ultimate reality". Based on these meanings seem the values are so decomposed from the meaning of etymologically the word Lombok and Sasak [1].

Sasak tribe cannot be separated with the island of Lombok in the north there Rinjani mountain. In the belief system Sasak Rinjani is the navel of the earth and at the same time as pasak bumi with various cosmological power possessed. This belief system gave birth to a variety of ceremonial systems and taboo systems in order to breed and honor as a form of gratitude. The offerings were performed, and the ritual traditions in the use and management of the Rinjani area were run in an attempt to keep the guard not angry, and the Rinjani area with all its 
ecosystems sustained. This cosmological view is reflected in the views, attitudes and behaviors that place spirituality as the focal point of decision making and the primary consideration in everyday life. In the spatial system, this cosmological view is expressed in the development of functional space or artificial space of the home environment, to a certain spatial region. Any artificial spatial development, must have cosmological concepts among others relating to the center of the image of space, direction, the wind, the calculation of good days and bad days, and others that describe the pattern of spiritual relationships between humans and spaces used for various activities.

Based on these cosmological views it can be concluded that the human cosmic center of Sasak is a spiritual symbol. This is evident in the spatial layout model (meso layout) as well as the tara of the house space (micro spatial arrangement) which places the mosque as the center of orientation and orbitation in spatial development. In traditional houses, there is an "abstract space" or spiritual space as the core of a house called bangaran or some who call it by the name of "ine bale" (parent house) or "bale dalem" (house in). In its development, as the transformation of the belief system of society increasingly crystallized, the economically capable families planned and built the prayer venue as an important part of the house, and placed in an accessible central position of all spaces.

\section{RESEARCH METHOD}

Methods in this study include Interviews, Types of interviews used here are structured interviews, namely interviews that interviewers set their own problems and questions that will be submitted to informants. As for the types of questions raised to informants in the form of structural questions as Spardley's phases of "progressive step forward", use descriptive questions [2]. Documentation, documentation becomes one of the important media to record intact. Documentation process is done after going through deep observation stage so that found object of study martial which relevant and significant. Documentation other than through recording media and photos is also supported by proper data analysis. The method of data interpretation with theoretical formulation is done by the method of "qualitative descriptive".

\section{RESULT AND DISCUSSION}

\section{A. Context Contents Rinjani Charter}

The following passage of the Rinjani Charter, with the grace of God Almighty, we as observers, beneficiaries and perpetrators of Rinjani Area conservation, praise gratitude for the gift of God who has granted "Mount Rinjani" as a source of life and livelihood that must be passed on to future generations [3].
1) We are cordial and agree that:

- The Rinjani area is the "Tri Kaya Atmaja Nira" which is recognized, respected, as a source of inspiration, a symbol of unification and harmony;

- The Rinjani area has panoramic beauty and natural resources of flora fauna, water, air, mines and minerals that are priceless;

- Rinjani area needs to have institutions, institutions and management systems that are based on justice, benefit and sustainability.

2) We express concern over:

- The destruction of Rinjani area caused by the decreasing of the quality of understanding and practice on norm, custom and religion values;

- The occurrence of biophysical damage Rinjani Region in the form of decreasing the beauty of panorama and natural resources resulting in horizontal and vertical conflict;

- The Rinjani Region and its spiritual values have not been established as a source of inspiration in the formulation of development and management policies that ensure the realization of a fair and sustainable benefit principle;

- The occurrence of omission and violation of customary law as well as state law by parties who should be guardians and implementers of law enforcement efforts;

3) Based on the above, we stated that:

- Given the importance of Rinjani Region's position and role, we agreed to restore the function of Rinjani Region, to maintain its sustainability and harmonious, balanced and sustainable management by referring to the philosophy of "Aik Meneng, Tunjung Tilah, Empak Odori";

- Need to be done immediately and continuously efforts to stop the destruction, including the privatization of life sources concerning the livelihood of the people;

- To that end, the strengthening and empowerment of local institutions, both institutional and social institutions must be done through concrete steps by giving recognition and respect for its existence, make efforts of revitalization and reconstruction and other measures that are constructive and creative.

- For anyone, who damages or lets damage inside or which affects the Rinjani Region, he is declared to be unlawful and disrespectful.

Thus the Rinjani Charter is created and mutually agreed upon to be implemented. Signed in Mataram on June 17, 2005, by five representatives of rural communities around Mount Rinjani, 5 government representatives and legalized by the Central Lombok Regent, West Lombok Regent and East Lombok Regent and Governor of NTB. 


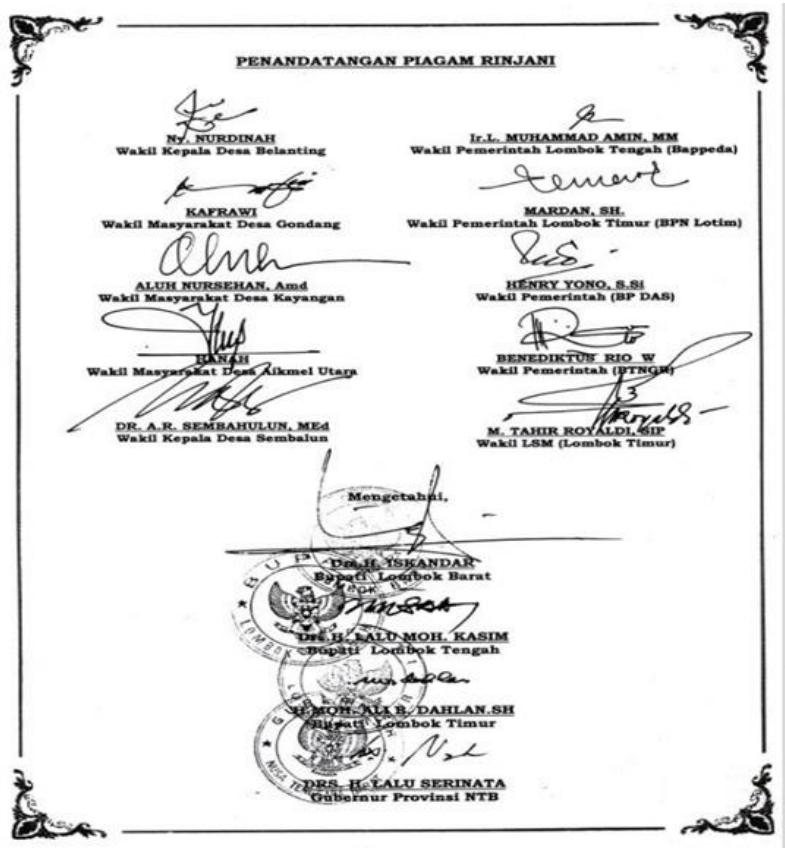

Fig. 1. The Rinjani Charter.

\section{B. Rinjani Charter in Sasak Life}

Rinjani Charter signed by stakeholders as a form of expectation towards Sasak natural and cultural conservation. The Rinjani Charter is essentially a contemplation of Sasak's view of Paer as mentioned above, covering geographical, sociological and cultural aspects or a unity of Nature and Culture. These attitudes and visions can be seen from the linkage and attachment between physical environmental conditions and the culture and value system governing social mechanisms. To maintain the preservation and balance of socio-ecosystems, the Sasak community develops a preservation mechanism with myth, maliq and various accompanying ritual traditions.

The view of the unity of nature and culture also gave birth to the wisdom associated with the management of nature, the arrangement of space and its functions, and the symbols relating to the belief in God and the occult which support the conservation of nature, culture and social value system. Thus it is assumed that the shift in value due to socio-cultural interaction will cause a change of view about human relationships with nature and will subsequently change people's behavior towards nature.

The "philosophy" preserves its sustainability and harmonious, balanced and sustainable management by referring to the philosophy of "Aik Meneng, Tunjung Tilah, Empak Odor"; it is in practice the life of the society is consistently charged as to where to manage Paer sasak and Rinjani as the center of Water remains clear among the Bunga Tunjung in its wholeness of beauty and the fish is harvested in happiness) " [4,5].
As the function has been pointed out earlier, paer is not only a geographical concept, but also a sociological concept even related to social psychology. The landscape is naturally besides functionally as a supporter of human existence, is also used as a medium to express itself emotionally. Cengkok tembang and kayaq (Sasak song) the northern part of the mountains will be different from the relatively flat southern regions. Geographical norms also affect the pattern of social interaction of the community, some are more open and some tend to be closed. Sociologically, the Sasak community has a psychological relationship with paer in different patterns. Some are explicitly expressed by implicit behavior, if the ecosystem is disrupted. The fragment of Tembang Pangiling Iling below gives the meaning of the noble value and the Sasak tribute to Mount Rinjani [3].

"Nuhun samia hanyungga Rinjani \{let us both guard Rinjani\}, mine the spirit of kunguripan manungsa $\{$ he is the spirit of human life\}, Kang cinipta dening Pangerana \{created by God Almighty\}, Balikna Rinjani iku \{Restore Rinjani\} paring pangkoning adat iki \{into our customary lap\}.

\section{CONCLUSION}

Gumi paer commonly called Paer is a symbolic formulation of Sasak people's understanding of space in cultural perspectives. Paer is not only a geographical and cosmological concept, but it also has sociological interpretations. In the belief system Sasak Rinjani is the navel of the earth and at the same time as pasak bumi with various cosmological power possessed. This belief system gave birth to a variety of ceremonial systems and taboo systems in order to breed and honor as a form of gratitude. Rinjani as the center of the cosmos and the ecological center (pasek gumi) of Lombok Island that flows water sources that affect the climatology and life of Lombok Island as the current understanding. The preservation of Rinjani is no longer a myth but as a cosmological reality. The birth of the Rinjani Charter signed on June 17, 2005 has an impact on the social function of the community, especially in the preservation of the environment and the life of the Sasak tribe which makes Mount Rinjani a source of life. The Rinjani Charter reinforces the desire of the Sasak people in the preservation of values, culture and life in a broad sense.

\section{REFERENCES}

[1] M. Antoro, Sejarah dan asal usul Lombok, Retrieved from http://wordpress.com, accesed 20 March 2017.

[2] J.P Spardly, The ethnographic interview, Wadsworth Publishing Company, 1979.

[3] T.S. Kukuh, Rinjani terluka! Jejak pergulatan mengembalikan makna, Mataram: Santiri, 2011.

[4] L.M. Amin, Formulasi Implementasi Piagam Rinjani dalam Rinjani Terluka, jejak pergulatan mengembalikan makna, Mataram: Santiri, 2009.

[5] U. Indah, Sejarah Keperbukalaan NTB, Nusa Tenggara Barat: Depdikbud, 2010. 